\title{
Rod photoreceptor rescue or degeneration
}

To the editor-We read with interest the article by Picaud and colleagues ${ }^{1}$ in the October issue of Nature Medicine. Evidence of rod and cone photoreceptor rescue by 1 -cis diltiazem was quantified using techniques of immunohistochemistry, electrophysiology and photoreceptor counting. Of note, the authors described a considerable photoreceptor rescue as demonstrated by opsin antibody staining, but only a moderate rescue as demonstrated by photoreceptor cell counts.

We have previously shown that an antibody against opsin that recognizes the $\mathrm{N}$ terminal of the opsin molecule (similar to the antibody used by Picaud et al.) labeled only the rod outer segments but not the perikarya of normal rod cells. However, in degenerating phoreceptor cells the rod perikarya were also labeled ${ }^{2}$. We believe that the immunolabeling noted in this study ${ }^{1}$ might represent degenerating photoreceptor cells and not surviving cells as claimed.

DEEPAK P. EDWARD ${ }^{1} \&$

MARK O.M. TSO ${ }^{2}$

\author{
'Department of Ophthalmology \\ UIC Eye Center \\ 1855 West Taylor Street (M/C 648) \\ Chicago, Illinois 60612, USA \\ ${ }^{2}$ Wilmer Eye Institute \\ Johns Hopkins School of Medicine \\ $600 \mathrm{~N}$ Wolfe Street \\ Baltimore, Maryland 21287 USA
}

Picaud and Sahel reply- Diltiazem was shown to slow down photoreceptor degeneration in the rd mouse, an animal model for retinitis pigmentosa ${ }^{1}$. Rod cell numbers were quantified after cell labeling with the rho-4D2 antibody directed against rhodopsin. This quantification was possible because the antibody labeled surviving rod cell bodies. Given their own experience with a rhodopsin antibody that failed to label rod cell bodies $^{2}$, Edward and Tso suggest that these labeled cells were perhaps degenerating photoreceptors.

However, it has been reported previously that rod cell body staining is not obtained with all rhodopsin antibodies ${ }^{3}$ but that rho-4D2 antibody does label rod cell bodies in the normal retina ${ }^{3}$ and in other conditions ${ }^{4}$. Therefore, we believe our rod cell count did estimate surviving photoreceptors and not degenerating cells.

\section{Serge Picaud \& José SAHel}

Laboratoire de Physiopathologie Cellulaire et Moléculaire de la Retine,

INSERM EMI-99-18, Universite Louis Pasteur,

Medicale A, BP426,

1 place de I'hopital,

cedex 67091 Strasbourg,

France

Email: picaud@neurochem.u-strasbg.fr

1. Frasson, M. et al. Retinitis pigmentosa: rod photoreceptor rescue by a calcium-channel blocker in the $r d$ mouse. Nature Med. 5, 1183-1187 (1999)..

2. Edward, D.P., Lim, K., Sawaguchi, S. \& Tso, M.O.M. An immunohitochemical study of opsin in photoreceptor cells following light-induced retinal degeneration in the rat. Graefe's Arch. Clin. Exp. Ophthalmol. 231, 289-294 (1993).

3. Hicks, D. \& Barnstable, C.J. A phosphorylationsensitive anti-rhodopsin monoclonal antibody reveals light-induced phosphorylation of rhodopsin in the photoreceptor cell body. Eur. I. Cell. Biol. 44, 341-347 (1987).

4. Hicks, D., Forster, V., Dreyfus, H. \& Sahel, J. Survival and regeneration of adult human photoreceptors in vitro. Brain Res. 643, 302-305 (1994).

\section{Celera: financial optimism, scientific skepticism}

Genome sequencing pioneer Craig Venter last month left Wall Street bewitched, his critics bothered, and much of the press bewildered with news that his company, Celera Genomics, has placed sequence data in its database "covering $90 \%$ of the human genome."

Celera's shares were already in favor with investors who had, for the previous few weeks, been buying heavily into genomics companies as a potentially lucrative investment. Within hours of the announcement, the shares shot up in value by almost $40 \%$, from what had already been a record high of $\$ 186$ to $\$ 258$, before settling back later in the day to $\$ 242$.

Those who argue that Venter's 'shotgun' approach to sequencing has limitations that can best be met by close collaboration with publicly funded, clone-by-clone strategies claimed that their perspective had been vindicated. This was based on Venter's admission that he had made heavy use of public data in reaching his self-declared "milestone."

But many were left asking whether it was reasonable that whereas Celera-like the rest of the research community-enjoys free access to the public data, the arrangement is not reciprocal. A statement from the company, although confirming that it eventually anticipated all the data being published openly in the scientific literature, also emphasized that the data were being made available "under a non-redistribution agreement" to Celera database subscribers.

The mass media seems confused by the significance of the company's statement that it had "compiled DNA sequence covering $90 \%$ of the human genome." A number of newspaper articles, including, for example, one in the Financial Times of London, subsequently reported that the company "had mapped $90 \%$ of the human genome." Some claimed that this gave it a substantial lead over publicly funded sequencing efforts, which are due to produce their own 'rough draft' of the genome in the summer. Few reported that this $90 \%$ included data obtained by Celera from the public databases, or that the company's own sequenced databases-covering $81 \%$ of the estimated 3.2 billion base pairs-needed the public data to be properly 'finished'.

Despite the reservations, the figures produced by Venter at his press conference were impressive. For example, he stated that the company's statistical analysis and comparison with known genes suggested that "greater than $97 \%$ of all human genes are represented in our database" (even if, as others points out, some are present in highly fragmented form).

David Dickson, London 